\title{
Teacher Candidates' Metaphorical Perceptions of Older Family Members
}

\author{
Filiz Gültekin ${ }^{1}$, Ahu Arıcıŏglu, \\ ${ }^{1}$ Faculty of Education, Uludag University, Turkey \\ ${ }^{2}$ Faculty of Education, Pamukkale University, Turkey
}

Copyright $\odot 2017$ by authors, all rights reserved. Authors agree that this article remains permanently open access under the terms of the Creative Commons Attribution License 4.0 International License

\begin{abstract}
This study was conducted on teacher candidates who had the opportunity to work with children, adolescents, young adults, adults and the elderly. We believed that determining the relationship between teacher candidates and their elders and their perceptions would help to plan classes and events for the elderly target group. For this purpose, the relationship between Physical Education and English Teacher and Psychological Counseling and Guidance senior students in education faculty and sport science faculty and their elders was investigated. Metaphors were examined and 13 different categories were developed based on common properties. When the results were investigated, the relationship were mostly defined as Restful ( $\mathrm{f}=11)$, Informative ( $f=10)$, and Cautious $(f=9)$. Other categories were listed as Commitment $(f=6)$, Reassuring $(f=6)$, Close $(f=5)$, Non-developing $(f=4)$, Appreciated $(f=4)$, Distanced $(f=4)$, Mandatory $(f=3)$, and Variable $(f=3)$. The categories with the least frequency were Conflicting $(f=2)$ and Cared $(f=2)$. According to the findings, it could be stated that teacher candidates had more positive perceptions towards their elders. Findings of the study are discussed below.
\end{abstract}

Keywords Teacher Candidates, Relationship with Grandparents

\section{Introduction}

As the living conditions became better due to developments in technology and science, human life had extended significantly. Correspondingly, the number of individuals in old age in society had increased drastically. Turkey is considered to be one of these societies. According to statistics, in 2012, the elderly population in Turkey was 5,682,003 and in 2016 the elderly population was $6,651,503$. The ratio of the elderly population among total population was $7.5 \%$ in 2012 , and had increased to $8.3 \%$ in 2016 [1]. Hence, according to the definition of the
United Nations, if the ratio of elderly population within a country is between $8-10 \%$, the population of that country is considered to be "old", whereas if the ratio is above $10 \%$, the population of that country is considered "very old" [1]. By this metric, the population of Turkey could be referred to as "old."

In addition to the global situation related to the elderly population, even though old age is the last stage of development, it is not possible to overrule or to ignore this stage. As in all other development stages, old age also witnesses various changes. Even though physical, mental, and functional losses in old age reveal psychological problems, wisdom, which is one of the most important cognitive properties, could emerge in old age [2].

In old age, visual and hearing losses [3], decreases in learning and memory capacity, longer reaction durations, and sleeping problems could significantly lower the quality of life [4]. Due to these possible health problems, old age could be perceived as a state to be avoided. Therefore, individuals could have negative attitudes and prejudices against old age.

Negative attitudes and prejudices towards old individuals and aging could lead to elder discrimination $[5,6,7]$. Some examples for negative attitude and prejudice towards old individuals could be given as follows; regarding elder individuals as intolerant, conservative, or obsessive people, regarding that older individuals had miserable and unhappy lives, they are isolated from society, they are dependent and non-productive individuals, and that they have physical and mental problems [8]. Ünalan, Soyuer, and Elmalı [9] stated that the negative attitudes of the society towards the elderly and aging could negatively affect the health services of elder people. A similar situation was valid for other services areas regarding physical, psychological, social, and cognitive development of elder people.

Dinçer, Usta, and Bulduk [10] stated that a comprehensive education should be planned and applied for the university students who could encounter elder individuals on every stage of their life. Negative attitudes 
toward elder individuals and aging could effectively be overcome with education. Therefore, teachers and students should gain positive attitude towards elder individuals with related classes and courses. Transferring these positive attitudes to the next generation using education was considered as an important attribute. The classes and courses in question could be beneficial for determining the perceptions of teacher candidates towards elderly individuals.

As mentioned earlier, there could be various physical and psychological problems in older age. Psychologic problems of elder individuals could be related with their experiences in their youth as well as certain developmental risk factors (loss of partner, retirement, menopause/andropause, social isolation, chronic illnesses, fear of being dependent, fear of death etc.) [11]. Accordingly individuals would require psychological help services during older age. Therefore, to meet this demand, there is a need for informed and skilled mental health experts.

Physical exercise was considered as an effective method to increase positive emotions and decrease negative emotions. For example, yoga could improve the psychological problems of elders (anger, anxiety, depression, well-being, self-sufficiency etc.), increase in sleeping quality and sufficiency, and a decrease in tiredness, and in depression levels [12, 13]. Physical exercise was also recommended for cognitive functions. Response time could increase, the mind could function properly, and reasoning could be more accurate when an individual regularly exercises $[14,2]$. When the importance of exercising in old age was considered, there would be a need for capable experts to work with this specific group.

Sensory stimulation was considered as one of the effective methods to avoid decelerating the learning ability in older age. When elder people retire and move away from social interaction, the cognitive abilities could decrease. As the social interaction levels increase; effort for internalization and coping increases and desperation decreases $[14,15,2]$. In sum, physical or cognitive socialization of elders could positively affect cognitive and psychological states.

Education teachers in Turkey were intended for pre-school, elementary, and high school education. However, increase in elder population and life-long learning approach; there is a need for creating new learning opportunities for elders. In this context, teacher candidates should gain information and skill to work with such groups. By determining the relationship between teachers and elder individuals as well as the attitude towards elder, could support to build related classes and events. Therefore, in this study, Psychological Counseling and Guidance, English and Physical education teacher candidates in the senior year who had the highest possibility to encounter elders were selected as the study group.
If we consider the increase in the elder population in Turkey as well as in other countries, services to ease the adaptation of elder individuals should be more common. According to literature, there were certain researches that investigated the perception of elder people $[16,10,17]$. To contribute to the visibility of this need, our study was based on a life-long learning approach and we investigated the metaphorical perception of teacher candidates towards older family members.

\section{Materials and Methods}

\subsection{Participants}

In this study, descriptive analysis was selected as one of the qualitative research patterns. Purposive sampling method which is the one of the improbable sampling technique was used to select the research sample. In qualitative research, the selection of the sample group considered appropriate for the purpose of the research is widely used. The participants of the study consisted of 2016-2017 academic year senior students from education faculties of two different universities (19-25 age, $\bar{x}=21,6)$. The participants of the study were selected among students who provide services to individuals in all development stages, from childhood to elderly life. Accordingly, total of 69 teacher candidates were selected from Psychological Counseling and Guidance (34), English Teacher (16), and Physical Education Teacher (19) departments.

\subsection{Procedures}

The data for the study was collected using a questionnaire that determined the relationship between participants and grandparents (if they haven't grandparents, other elder people in their family) and the questions had the questionnaire of "My relationship with my grandparents is like ...., because....". Data collection was conducted in two ways. Some of the participants were given questionnaire in the class environment and the participants answered the questions on these questionnaires. The remaining participants had received the questionnaire in e-mail format and the questions were answered. The objective of the study was explained written and oral forms.

\subsection{Data Analysis}

The data of the study were investigated using metaphor analysis of qualitative data analysis techniques. Morgan [18] stated that metaphors could be used for two purposes; stating a status and accelerating or improving a process. Metaphors were depicted as they are when there was a state, event or phenomena. In this study, metaphors were used for descriptive purposes.

When the researches on metaphor analysis were 
investigated $[19,20,21,22,23,24,25,26]$, the stages were analysis and interpretation, denotation, classification, category development, reliability and validity. In this study, data analysis and interpretation was as follows:

In the first stage of data analysis, a table was created with metaphors of the participants and explanations about these metaphors. 22 participants who had not defined any metaphor or had not provided an explanation were excluded from the study.

In the second stage, the answers that will be evaluated were investigated in terms of content. Moser [27] stated that metaphorical structure of a statement depends on the context. For example, when "it has gone beyond the borders" statement was used in a tennis match context, the statement was not considered as a metaphorical expression, because "tennis ball" physical boundaries of the tennis court. Same statements were metaphorical when it was referenced to behaviour. For example, "the behaviours have gone beyond the borders" Here, behaviour was explained using a sports term and the suitability of the behaviour was tried to be explained. Therefore, metaphors of the participants, subject of metaphor, source of metaphor, and the relationship between these two were investigated. The investigation showed that not all participants had generated valid metaphors. These metaphors were stated as "weak structured metaphors." The evaluation was based on whether the metaphor had source, whether there were logical reasons, whether the metaphor had more than one category, and whether the concept was understandable. Some examples for the weak structured metaphors based on these criteria were given as follows:

My relationship with my grandparents is like a grandchild, because I am their grandchild. (Source domain of the metaphor was not present.)

My relationship with my grandparents is like a grandchild relationship, because we cannot talk like friends as we cannot see each other frequently. (Source domain of the metaphor was not present.)

My relationship with my grandparents is like the pictures on the fairy tale books, because I have the grandfather and grandmother like the fairy tales. (Reason or logical support was not present.)

My relationship with my grandparents is like a glass full of water, because the love between us means something. (Reason or logical support was not present.)

My relationship with my grandparents is like the sea, because it is wavy. Sometimes they are too close and sometimes they are far away. Our relationship can change, like the sea. No matter what condition the sea has, I know it exists and I know I will continue to exist. (Includes more than one category)

My relationship with my grandparents is like love, because a person first loves his/her mother and father and therefore, the family of this unique family is important to me. Love is the priority and each individual could have a different family relationship. But I love mine like love. I can take credit of their work and I am proud. (Includes more than one category)

My relationship with my grandparents is like a boss and favoured employee, because we care for respect and we can preserve this respect without going to extremes. It is not too friendly or too official. (Illogical or does not contribute to meaning of the concept.)

My relationship with my grandparents is like a friend, because I am a warm person. (Illogical or does not contribute to meaning of the concept.)

After 35 weak structured metaphors were excluded, total of 69 valid metaphors were present. In the third stage, metaphors generated by participants towards their grandmother and grandfather were categorized based on common properties. In these processes, 13 different styles conceptual categories were achieved. When the categories were generated, statements such as since grandparents are at the last stage of their life, this relationship is defined as losable, were included underappreciated category. One the metaphors included in this category was as follows: $M y$ relationship with my grandparents is like a flower about to wither, because they are becoming more fragile day by day. I realize that their life on this earth is close to the end and I am talking to them as if I am watering, loving, and look them for the last time. I am looking at them as I regret of the past since I didn't pay attention to them. Similarly, statements that emphasized to be a part of a whole were included in connectedness category. For example, my relationship with my grandparents is like the two halves of an apple, because they have separate places in my hearth. The categories were as follows: connectedness, cared, informative, conflicting, variable, non-developing, reassuring, restful, cautious, appreciated, distances, close, and mandatory.

In this study, when weak structured metaphors were determined and when categories were generated, the evaluations were separate. Two evaluations were merged and after a consensus was achieved in all metaphors, the last form of metaphor and category list was provided.

In the last stage, to test the validity and reliability, the reasons to use methods and patterns, properties of the study group, how the data was collected were investigated and the results were presented. Yıldırım and Şimşek [28] stated that reporting the data in detail and explaining how the results were obtained, was an important validity measurement. In this context, the data analysis processes (and especially how the conceptual categories were generated) was explained in detail. Ekiz [29] stated that one of the validity types in qualitative analysis was descriptive validity. Descriptive validity could be defined as the validity that presents the subject of investigation in reality without altering or selecting the results based on the perspective of the researchers. In this sense, each metaphor and corresponding statement were given as examples. The 
statements were presented as direct quotes, and the descriptive validity of the research was tried to be obtained.

For the internal consistency of the research, metaphors presented under 13 conceptual categories were presented to experts to determine whether the conceptual category in question reflects the metaphors. Therefore, two lists including metaphors and conceptual categories were presented to a faculty member who had prior knowledge on qualitative research. The expert was asked to match the metaphors on the first list to the categories in the second list. Additionally, the expert was reminded that he/she could create a different category. The matching of the expert was compared with the matching of the researches. According to the comparison, consensus and divergence were considered and Miles and Huberman [30] formula (reliability $=$ consensus $/$ (consensus + divergence $) \times 100)$ was used for calculating the reliability of the research. Expert had placed nine metaphors in different categories. The reliability was calculated as $(60 / 60+9) \times 100=87 \%$ and the reliability of the study was inside the acceptable region.

\section{Findings}

In this section, the findings were presented regarding the metaphors of the teacher candidates towards grandparents. Below, these categories and correspond metaphors were explained. Additionally, direct quotes from the statements of the participants were included.

\subsection{Conceptual Categories Regarding the Relationship with Grandparents}

When Table 1 was investigated, it could be seen that participant have stated metaphors in Restful $(f=11,15.9 \%)$ and Informative $(f=10,14.5 \%)$ categories. The least number of metaphors could be observed in Cared $(f=2$, $2.9 \%)$ and Conflicting $(f=2,2.9 \%)$ categories. Categories in question, general properties of these categories, and statements of the participants regarding the metaphors in the related category were stated below.

\section{Category 1: Relationship Based on Connectedness}

There are 6 metaphors under this category. In this category, majority of the participant had used the metaphors of tree or plane tree. Metaphors generated in this category were emphasizing to be a part of a whole, lineage connection, and being a member of the same family. Below, examples from the statements of the participants were presented for the metaphors.

My relationship with my grandparents is like a plane tree, because I am the branches and they are the root of the tree.

My relationship with my grandparents is like a train wagon, because even though it is not attached to the train, the wagon is a part of the train.

My relationship with my grandparents is like the two halves of an apple, because they have separate places in my hearth.

Table 1. The frequency (f) and percentage (\%) values of conceptual categories for metaphors

\begin{tabular}{|c|c|c|c|}
\hline Categories & Metaphors & $f$ & $\%$ \\
\hline Commitment & tree(1), plane tree(3), the two halves of an apple(1), wagon (1) & 6 & 8,7 \\
\hline Cared & taking care of a flower(1), child(1) & 2 & 2,9 \\
\hline Informative & $\begin{array}{l}\text { a growing plant(1), a story teller(1), book(1), teacher and student(3), a person with a } \\
\text { compass(1), reading a history book(1), a master and an apprentice (1), candle(1) }\end{array}$ & 10 & 14,5 \\
\hline Conflicting & cactus(1), a magnet with opposite sides(1) & 2 & 2,9 \\
\hline Variable & $\begin{array}{l}\text { the sea that sometimes calm and sometimes stormy (1), apple(1), a couple who is } \\
\text { fighting(1) }\end{array}$ & 3 & 4,3 \\
\hline Non-developing & sinking ship(1), a still river(1), an old record(1), spinach and yogurt(1) & 4 & 5,8 \\
\hline Reassuring & $\begin{array}{l}\text { a huge plane tree and a beautiful daisy right under the tree(1), iron(1), like the leaves } \\
\text { of a tree that will never dry(1), my favourite book on the shelf(1), a harbour to } \\
\text { shelter (1), old tree(1) }\end{array}$ & 6 & 8,7 \\
\hline Restful & $\begin{array}{l}\text { a kitten and mother cat }(1) \text {, the voice of a rain droplet (1), hammock(1), short coffee } \\
\text { breaks in life }(1) \text {, a cake with cream }(1) \text {, cotton candy(1), the stove to get warm in the } \\
\text { winter(1), holiday }(1) \text {, the smell of earth }(1) \text {, summer(1), stars and Earth(1) }\end{array}$ & 11 & 15,9 \\
\hline Cautious & $\begin{array}{l}\text { child(1), breadcrumb(1), adolescence(1), plum(1), a precaution for flood(1), } \\
\text { candy(1), scales(1), iron(1), ventilator(1) }\end{array}$ & 9 & 13,0 \\
\hline Appreciated & $\begin{array}{l}\text { old radio(1), an opportunity that will never happened(1), soap(1), a flower about to } \\
\text { wither (1) }\end{array}$ & 4 & 5,8 \\
\hline Distanced & appetizer(1), ice(1), winter(1), a fruit tree(1), & 4 & 5,8 \\
\hline Close & $\begin{array}{l}\text { two good friends(1), kitten(1), metin-ali-feyyaz (1), a cool breeze(1), summer } \\
\text { rain(1) }\end{array}$ & 5 & 7,2 \\
\hline Mandatory & commander and soldier(1), a gift I don't like(1), teeter totter(1) & 3 & 4,3 \\
\hline Total & & 69 & 100,0 \\
\hline
\end{tabular}




\section{Category 2: Caring Relationship}

There are 2 metaphors under this category. Metaphors generated in this category showed that grandparents were in need of care, compassion, and interest. Below, examples from the statements of the participants were presented for the metaphors.

My relationship with my grandparents is like taking care of a flower, because they both need to be loved and taken care of.

My relationship with my grandparents is like a child, because they need compassion and patience.

\section{Category 3: Informative Relationship}

There are 10 metaphors under this category. In this category, majority of the participant had used the metaphors of teacher and student. It was shown that metaphors generated in this category reflect the relationship of a teacher and learner. Statements in this category emphasized guidance, teaching, educating, instructing, and showing the correct behaviour. Below, examples from the statements of the participants were presented for the metaphors.

My relationship with my grandparents is like a growing plant, because I feel like they nourish me with their knowledge, and experiences.

My relationship with my grandparents is like a story teller, because when I listen to them and hear about the past and I am happy. They like talking about the past.

My relationship with my grandparents is like a book, because when I have a conversation with them, I learn new things or gain new knowledge.

My relationship with my grandparents is like teacher and student, because I have learned many of the information from them and they have generally guided me about what is right and wrong.

My relationship with my grandparents is like a person with a compass, because they always show me the right way and try to comply.

My relationship with my grandparents is like reading a history book, because I gain information about the past.

My relationship with my grandparents is like a master and an apprentice, because they work hard to raise me well.

My relationship with my grandparents is like a candle, because when I am far away, thee light is low but they can illuminate my life with suggestions and prayers. If I am left alone in the darkness, I can always consult to them.

\section{Category 4: Conflicting Relationship}

There are 2 metaphors under this category. Metaphors in this category showed that communication and generation conflicts were emphasized. Statements in this category showed the different perspectives due to the generation. Below, examples from the statements of the participants were presented for the metaphors.

My relationship with my grandparents is like a cactus, because I have sharp-tongue.

My relationship with my grandparents is like a magnet with opposite sides, because their generation is different than my generation and this difference causes the idea conflicts.

\section{Category 5: Variable Relationship}

There are 3 metaphors under this category. It was shown that metaphors generated in this category were defined with opposite adjectives. In this category, partially negative and partially positive relationships were emphasized. Below, examples from the statements of the participants were presented for the metaphors.

My relationship with my grandparents is like the sea that sometimes calm and sometimes stormy, because in different phases of my life, I had conflicts with them, however there were some stages where we had a good communication.

My relationship with my grandparents is like an apple, because it has different varieties and they taste different. My relationship with them changes by the person. It is like apples with different types and tastes. Our relationship is sometimes sweet and sometimes sour.

My relationship with my grandparents is like a couple who is fighting, because they are offended by everything and can be like a child but they will forgive me in no time.

\section{Category 6: Non-developing Relationship}

There are 4 metaphors under this category. Metaphors generated in this category emphasized non-educating and non-guiding, boring, and monotonous relationship. Below, examples from the statements of the participants were presented for the metaphors.

My relationship with my grandparents is like a sinking ship, because we always talk about memories and sinking moments.

My relationship with my grandparents is like a still river, because we have a normal relationship without ups and downs.

My relationship with my grandparents is like an old record, because whenever I talked with my grandfather, he always tells me his old memories and they are always the same. When he talks about his memories, he becomes happy and remembers these days.

My relationship with my grandparents is like spinach and yogurt, because they are served together but they do not have nutrient when they are together.

\section{Category 7: Reassuring Relationship}

There are 6 metaphors under this category. It was shown that metaphors generated in this category reflect solidness, 
continuity, and protectiveness. Statements in this category emphasized protective and solid relationship that comes from past and will continue in the future. Below, examples from the statements of the participants were presented for the metaphors.

My relationship with my grandparents is like a huge plane tree and a beautiful daisy right under the tree, because their spiritual glory, their experiences and their previous life had always affected me. I always know that I am under their shadow and these shadows will protect me from sun, not from the drop of water that will give life.

My relationship with my grandparents is like iron, because we have a strong relationship based on past.

My relationship with my grandparents is like the leaves of a tree that will never dry, because we will always embrace each other with commitment, love, and respect and this will never change.

My relationship with my grandparents is like my favourite book on the shelf, because whenever I want to reach them, they are always there right by my side. Whenever I have problem, I feel bad, or I am miserable, I try to reach my favourite book.

My relationship with my grandparents is like a harbour to shelter, because when I have a problem or I worry about something, their experiences, ideas, knowledge, love, and compassion will be my shelter. When I talk to them and exchange ideas, I feel safe and secure. Therefore, I would like to state the relationship as a harbour. It is good to have a harbour to shelter. My first harbour is my family, then my grandmother and my grandfather.

My relationship with my grandparents is like an old tree, because as the old tree resists to harsh winter environments, a family with close bonds will do the same. To overcome the difficulties, family members should have strong bonds to support and help each other. Therefore, our mother and father are like the roots of this tree. They are biggest supporters against life. They always protect us from evil.

\section{Category 8: Restful Relationship}

There are 11 metaphors under this category. Metaphors generated in this category emphasized calm, relaxing, intimate, happy, and joyful aspects of the relationship. Below, examples from the statements of the participants were presented for the metaphors.

My relationship with my grandparents is like a kitten and mother cat, because they are soft and warm like cats. When I hug them, I feel peaceful.

My relationship with my grandparents is like the voice of a rain droplet, because it is relaxing.

My relationship with my grandparents is like a hammock, because when I am with them, I can enjoy the slowly swinging hammock and I can go back to my childhood.

My relationship with my grandparents is like short coffee breaks in life, because I found it sincere and enjoyable.

My relationship with my grandparents is like a cake with cream, because it gives love and happiness, when I eat the cake I become happy and it does not want anything back. Just like my grandparents. They do not expect anything else other than my love and they give their love to me.

My relationship with my grandparents is like cotton candy, because since we always lived far away from our home town, we were always with them in the holidays. They liked us very much. They always did what we asked from them. My best memories were in the house of my grandmother and grandfather. They were always helpful to anyone not just to us.

My relationship with my grandparents is like the stove to get warm in the winter, because we went to see them for a while each year. They do not hug or kiss, but they always warm me when I sit next to them.

My relationship with my grandparents is like holiday, because whenever I am with them, I feel happy and safe. Of course, since I always see them on holidays, this affects my perspective.

My relationship with my grandparents is like the smell of earth, because the smell is always the same but it always makes me happy.

My relationship with my grandparents is like summer, because they make me fell the warmth of summer.

My relationship with my grandparents is like stars and Earth, because I know that they add beauty in my life. They won't be in every stage of my life, but I am glad they are here now.

\section{Category 9: Cautious Relationship}

There are 9 metaphors under this category. Metaphors in this category emphasized cautious relationship. Statements in this category reflected a balanced relationship should be obtained. Otherwise, it is stated that the parties will get hurt, sad, and the relationship could be broken. Below, examples from the statements of the participants were presented for the metaphors.

My relationship with my grandparents is like a child, because they are over sensitive and understand everything on the wrong way. Therefore, we do not tell many jokes.

My relationship with my grandparents is like breadcrumb, because you can enjoy eating bread. You like the elder people. But you can hurt them even if you don't mean to. But the crumbs will not change the taste of the relationship. If you hurt them too much, your relationship will become insatiable. Both sides will suffer.

My relationship with my grandparents is like adolescence, because they are too sensitive.

My relationship with my grandparents is like plum, because you want to eat it but your stomach aches later. Normally my relationship is good but if I am too close, things go wrong.

My relationship with my grandparents is like a 
precaution for flood, because possibility of flood is always high. But if you take precautions, you can prevent the flood.

My relationship with my grandparents is like a candy, because candy can harm you but it is generally good. When your sugar level is high, you can hurt other people as well. But it generally leaves a sweet taste.

My relationship with my grandparents is like scales, because it is balanced.

My relationship with my grandparents is like iron, because when you increase the temperature you can iron well but you will also burn the cloth.

My relationship with my grandparents is like ventilator, because you can only use it in certain periods. It can cool you down but if you are in front of the ventilator. It won't dry the air like air-conditioner, but it is still an old tool.

\section{Category 10: Appreciated Relationship}

There are 4 metaphors under this category. Metaphors in this category showed that grandmother and grandfather were seen as individuals who are at the last stage of their life. Therefore, the participants defined their relationship with their grandparents as a valuable relationship that can be lost in any minute. Below, examples from the statements of the participants were presented for the metaphors.

My relationship with my grandparents is like an old radio, because sometimes the interference in the sound bothers me however it is extremely important and valuable for me. Seeing it in the corner in one piece makes me relief.

My relationship with my grandparents is like an opportunity that will never happened, because since I am in another city, I can hardly see them and I miss them, we need to appreciate the time we are spending together

My relationship with my grandparents is like a soap, because when I want to hold it, it will slip at some point.

My relationship with my grandparents is like a flower about to wither, because they are becoming more fragile day by day. I realize that their life on this earth is close to the end and I am talking to them as if I am watering, loving, and look them last time. I am looking at them as I regret of the past since I didn't pay attention to them.

\section{Category 11: Distanced Relationship}

There are 4 metaphors under this category. Metaphors in this category emphasized distanced and insatiable relationship. Statements in this category had the common property of not feeling close and not seeing frequently. Below, examples from the statements of the participants were presented for the metaphors.

My relationship with my grandparents is like appetizer, because it is neither fulfilling nor cold.

My relationship with my grandparents is like ice; I cannot even call it a relationship. They are actually warm and moderate. However, I don't prefer to be involved in a relationship. Maybe it is because we always lived in different cities.

My relationship with my grandparents is like winter, because I don't feel close to them and I think things are cold between us.

My relationship with my grandparents is like a fruit tree, because we see each other only in the summer.

\section{Category 12: Close Relationship}

There are 5 metaphors under this category. Metaphors in this category emphasized close, friendly, comfortable, and engaging relationship between grandparents. Statements in this category correspond to love and understanding. Below, examples from the statements of the participants were presented for the metaphors.

My relationship with my grandparents is like two good friends, because both sides will not hurt each other or make them sad.

My relationship with my grandparents is like a kitten, because they always love me.

My relationship with my grandparents is like Metin-Ali-Feyyaz ${ }^{l}$, because I can tell everything comfortably.

My relationship with my grandparents is like a cool breeze, because even though there are conflicts and disagreements, we could solve these without hurting each other.

My relationship with my grandparents is like a summer rain, because even though we could not agree on some points, we can listen to each other in a calm manner.

\section{Category 13: Mandatory Relationship}

There are 3 metaphors under this category. Metaphors generated in this category emphasized a mandatory relationship to be endured for the family without any closeness. Statements in this category also emphasized the relationship as a duty to be fulfilled, realized, and respected. Below, examples from the statements of the participants were presented for the metaphors.

My relationship with my grandparents is like commander and soldier, because I feel like it is our duty to make them happy, our mother and father had done this for a life time so now it is our turn.

My relationship with my grandparents is like a gift I don't like, because I don't buy a gift ordinarily. I am having a relationship with my grandmother and grandfather because we are related and because they are older than me.

My relationship with my grandparents is like teeter totter, because even though I am weak, I always feel like I need to keep them high and if I leave the teeter totter, there

1 Metin-Ali-Feyyaz were three football players who played in the same team during 1985-95 season. In Turkey, this definition is preferred when the conditions are inseparable. 
is an option for them to get hurt (get sick).

\section{Discussion}

This study was conducted on teacher candidates who had the opportunity to work with children, adolescents, young adults, adults and the elderly. For this purpose, we had asked senior students from three different majors in education and sport science faculty how they perceive their relationship with their grandparents. Metaphors were investigated and 13 different categories were developed based on common properties. When the findings were investigated, the relationship were mostly defined as Restful, Informative, and Cautious $(f=9)$. The categories with the least frequency were Conflicting and Cared. According to these findings, it was shown that the relationship between teacher candidates and their grandparents were positive, close, and has safety emotions. On the other hand, the findings showed that the relationship should have cautious structure. Findings of this study share similarities with results of $[17,31,10]$. Similarly, Boz et al. [16] stated in their study on health science students that an elder individual in the family, living with them or seeing them frequently, increased the positive attitudes toward elders.

Participants had defined grandparents as soft, sweet, sparkling object or states with the metaphors generated in Restful category. Hazer [32] stated that based on the traditional structure of Turkish society, love for grandchildren has a separate place, and taking care of grandchildren, spending time with them, and helping the parents was considered as a happy experience. Therefore, establishing a relationship with the grandchildren generates spiritual satisfaction on grandparents. Grandparents regarded their grandchildren as more valuable than their own children [33]. Therefore, it could be stated that grandparents have closer, warmer, and satisfactory relationship with their grandchildren.

When the metaphors in Informative category were investigated, it could be seen that participants perceive the relationship with grandparents as a guidance, consultant, and education. Even though old age was regarded as a period where cognitive losses appear; it will be inappropriate to state this period is on standstill or regression. Onur [2] stated that in the old age, one of the most valuable cognitive properties, wisdom, could become visible. Wisdom is a type of information that provides the reality, meaning, and purpose of life. Traditionally, it was expected that wisdom increases with age and it is considered as a cognitive dimension. It is the quality of human behaviour and understanding. It is the combination of intuition, enthusiasm, and knowledge that could be hard to achieve with few life experiences [2]. In this sense, it could be said that participants were benefiting from life-long experiences of the individuals.
The meaning of the elder people could differ in each society. In the Turkish context, elder people were regarded as individuals who can transfer the experiences in life. Ögel [34] stated that "wise man" understanding was one of the most common beliefs in old Turkish tribes. In other words, elder people were considered as wise man in fables, fairy tales, stories, legends, and daily routine of Turkish society. We think that metaphors generated by the participants were projecting this situation.

Metaphors in Cautious category defined the relationship with grandparents as beautiful if there were boundaries; however, the individuals should always be cautious since anything could go wrong. The explanations of this category emphasized that grandparents were resentful. Decrease in physical strength, health impairments, children taking their decisions as adults could lead the elder individuals to think that they are no longer needed. However, McCrae and Costa [35] stated that personality is constant in adulthood, and there could be slight changes after 30 . The authors emphasized that typing elder people as withdrawn, depressive, or rigid were unfounded. From this point of view, perceiving the grandparents as resentful could be caused by differences in perspective. Different generations could emphasize different meanings to same values; therefore could have different perspectives. Thus, this situation could lead conflicts and offense between two generations. It is believed that this explanation is valid for the participant who had described their relationship with grandparents as Variable. Metaphors in this category defined the relationship with grandparents as a relationship with positive and negative sides. It is believed that this situation directs young people to be more cautious towards elders. It is though that perceiving the grandparents could die anytime could lead for such perspective. In this study, metaphors in Appreciated category showed that young people defined grandparents as individuals on the last stage of their life; therefore, these individuals should be appreciated.

Some participants defined the relationship as Connectedness, Restful, and Close. Altan [36] emphasized that Turkish family structure and function do not change in the same manner. This means while extended family structure transformed into elementary family structure, family and affinity relationships were still important. Even though people no longer share the same house, support and help continued to exist. In addition to monetary support, help was requested from mothers and fathers for child care where care and livelihood of elder mother and father was on adult children. In another words, in Turkish society, parents were always ready to help their children even though they are adults. It is considered as the fundamental component of being a family. Thus, family members could feel safer. The safety feeling provided individuals to view themselves as an inseparable part of a whole. Hence, in Connectedness category, the "whole" created by the family members was emphasized. This bound within the 
family provided opportunity to strengthen the communication, to increase the trust and appreciation between family members, therefore to establish a closer relationship.

Although the number was low, some of the participants defined the relationship with their grandmother and grandfather as Conflicting, Distanced, and Non-developing. This situation could be caused by the development needs of individuals in different development periods and differences in living purposes. Uçanok [37] stated that young adults mainly emphasized work, family, and economic objectives whereas the elder individuals emphasized health, social activities, and personal interests. In other words, living purposes, people in their lives, status, and values could also change among individuals in different development period. This situation could create conflicts.

Some of the participants defined the relationship with their grandparents as Mandatory. Taşçı [38] stated that being old in traditional family context (either for male or female) meant being "responsible", however, as the family structures begin to change this meaning has shifted to "problematic". Although there are certain changes in the Turkish society, traditional family type is still valid. Most of the male population desired to grow old with their sons. They believe their status will increase [39]. As the participants perceived the relationship between them and their grandmother and grandfather could be the projection of a cultural acceptance. However, dealing with the elderly, who become individuals who need to be cared for due to declining age and deteriorating health, can become a troublesome process for caregivers. Bilgili [40] stated that $63.3 \%$ of the individuals who provided elderly care had negative attitudes towards living together with elderly people due to mental states of the individuals. Çatak, Öner, Kılınç, Sütlü, and Şenbayram [41] stated that approximately six out of ten home caregivers for elderly did have mental symptoms. In conclusion, communication with elderly people could be challenge process for individuals. However, participant who perceived grandparents as Cared individuals and individuals who live in a culture where care for elderly is a responsibility, the relationship with grandparents could be perceived as mandatory.

\section{Conclusions}

This study was conducted on teacher candidates who had the possibility to work with individuals in different developmental stage. For this purpose, the relationship between Physical Education and English Teacher and Psychological Counseling and Guidance senior students in education faculty and sport science faculty and their elder was investigated. Metaphors were investigated and 13 different categories were developed based on common properties. When the results were investigated, the relationship were mostly defined as Restful ( $\mathrm{f}=11)$, Informative $(f=10)$, and Cautious ( $\mathrm{f}=9)$. Other categories were listed as Commitment $(f=6)$, Reassuring $(f=6)$, Close $(f=5)$, Non-developing $(f=4)$, Appreciated $(f=4)$, Distanced $(f=4)$, Mandatory $(f=3)$, and Variable $(f=3)$. The categories with the least frequency were Conflicting and Cared. According to the findings, it could be stated that teacher candidates had more positive perception towards elders.

The elderly population is rapidly increasing in Turkey as well as in other countries around the world. In this context, care and treatment services for elder individuals would be insufficient for their development and life satisfaction. In line with lifelong learning approach, by supporting the development of elder people, it is possible to create new business fields for young people. In our country, teachers are only considered in pre-school, elementary, and high school education. Teacher candidates in the education faculty are educated according to this approach. However, some of the faculties included in this study as well as other foreign languages departments, and fine arts departments have the opportunity to work with all age groups. Yet, when the programs were investigated, it can be seen that the students in these departments only had developmental psychology and no other classes related with elder individuals. Broadening their knowledge in this area could increase the opportunity to find a job. Therefore, classes regarding to working with elder people could be added to programs.

In this study, the perception of the participants towards grandparents was determined positive. Class subjects could be created based on this information. In the future researches, relationship or perception of the teacher candidates in other departments towards elder individuals could be investigated. In line with the positive/negative perception, class subjects could be adjusted to change the negative perception and eliminate the prejudices.

In this study, the participants were asked to define what did the relationship between them grandparents resembled to. In this sense, the study was limited with the elder people in the family of participants. Future researches could try to determine the perception related with old age, towards elder people, and with elder people.

\section{REFERENCES}

[1] Türkiye İstatistik Kurumu (2016), İstatistiklerle Yaşl1lar, Online available from htpp://www.tuik. gov. tr/Haber Bülteni.

[2] B. Onur. Gelişim Psikolojisi: Yetişkinlik, Yaşl1lık, Ölüm Developmental Psychology: Adulthood, Old Age, Death], İmge Kitabevi, Ankara, 2000.

[3] T. Örnek, E. Bayraktar, E. Özmen. Geriatrik Psikiyatri. [Geriatric Psychiatry], Saray Tıp Kitabevleri, İzmir, 1992 
[4] B. Altay, İ. Aydın Avcı. Huzurevinde yaşayan yaşlılarda özbakım gücü ve yaşam doyumu arasındaki ilişki. [The relation between the self-care strength and life satisfaction of the elderly living in nursing home], Dicle Tip Dergisi, Vol. 36, No.4, 275-282, 2009.

[5] N. Çilingiroğlu, S. Demirel. Aging and ageism. Turkish Journal of Geriatrics, Vol.7, No.4, 225-230, 2004.

[6] Ö. Özdemir, N. Bilgili. Sağlık hizmetlerinde yaşli ayrimciliğ 1 [Ageism in health care], Gülhane Tıp Dergisi, Gulhane Medical Journal, Vol.56, No. 2, 128-131, 2014

[7] G. Köse, H. Ayhan, S. Taştan, E. İyigün, S. Hatipoğlu, C. H. Açıkel, Sağlık alanında farklı bölümlerde öğrenim gören öğrencilerin yaşlı ayrımcılığına ilişskin tutumlarının belirlenmesi [Determination of the attitudes of students from different department in the field of health on the discrimination against the elders]. Gülhane Tip Dergisi, Gulhane Medical Journal, Vol.57, No.2, 145-152, 2015.

[8] Y. A. Momtaz, T. A. Hamid, R. İbrahim. Cohort comparisons: Emotional wellbeing among adolescents and older adults. Clinical Interventions in Aging, Vol. 9, 813-817, 2014.

[9] D. Ünalan, F. Soyuer, F. Elmal1, Geriatri merkezi çalışanlarında yaşlı tutumunun değerlendirilmesi. Kafkas Tıp Bilimleri Dergisi, Vol. 2, No.3, 115-119, 2012.

[10] Y. Dinçer, E. Usta, S. Bulduk. Üniversite öğrencileri gözüyle yaşlilik nasil algılanıyor? [How do university students view elderliness?] Elderly Issues Research Journal, Vol. 9, No.1, 2016.

[11] B. Cangöz. Yaşl1lıkta bilişsel ve psikolojik değişim. Türk Geriatri Dergisi, Vol. 19, 99-104, 2009.

[12] J. Halpern, M. Cohen, G. Kennedy, J. Reece, C. Cahan, A. Baharav. Yoga for improving sleep quality and quality of life for older adults. Alternative Therapies, Vol.20, No.3, 37-46, 2014

[13] B. B. Kimberleeand, G. Tenenbaum, Effects of yoga on psychological health in older adults. Journal of Physical Activity and Health, Vol. 11, $1334-1341,2014$.

[14] M. K1lıç. Gerçek Yaşam Tadında: Gelişim Dönemleri 3 Yaşlılık ve Yetişkinlik. Ankara: Pegem Akademi, 2013.

[15] M. Aközer, C. Nuhrat, Ş. Say, Türkiye'de yaşll1ık dönemine ilişkin beklentilerin araştırılması. [Expectations Regarding Old Age in Türkiye], Aile ve Toplum, Vol.7, No.27, 103-128, 2011

[16] H. Boz, et al. Sağllk bilimleri fakültesi ve iktisadi ve idari bilimler fakültesi öğrencilerinin yaşlı ayrımcılığına ilişkin tutumlar1 [Comparison of attitudes of faculty of health sciences and faculty of economics and administrative sciences' students towards elder discrimination], Kastamonu Sağlık Akademisi, Vol.1, No. 1, 32-54, 2017.

[17] Ş.D. Güven, G.U. Muz, N.E. Ertürk. Üniversite öğrencilerinin yaşlı ayrımcıllı̆ına ilişkin tutumları ve bu tutumların bazı değişkenlerle ilişkisi. Anadolu Hemşirelik ve Sağlık Bilimleri Dergisi, Vol.15, 99-105, 2012.

[18] G. Morgan. Accounting as reality construction: towards a new epistemology for accounting practice. Accounting, Organizations and Society, Vol.13, No.5, 477-485, 1988.
[19] T. Altun, F. Camadan. Rehber öğretmenlerin rehber öğretmen (psikolojik danışman) kavramına ilişkin algilarının metafor analizi yoluyla incelenmesi. [Examination of counseling teachers' perceptions on school counselor (psychological counselor) concept through Metaphor analysis], Kastamonu Eğitim Dergisi, Vol. 21, No.3, 883-918, 2013.

[20] F. Aydın. Ortaöğretim öğrencilerinin coğrafya kavramına ilişkin sahip oldukları metaforlar. [Secondary school students' metaphors about the geography concept.], Kuram ve Uygulamada Eğitim Bilimleri, Vol.10, No.3, 1293-1322, 2010.

[21] B.Eraslan Çapan, Öğretmen adaylarının üstün yetenekli öğrencilere ilişkin metaforik algıları. [Teacher candidates' metaphoric perceptions of gifted students.], Journal of International Social Research, Vol.3, No.12, 2010.

[22] E. Aydoğdu, İlköğretim okullarındaki öğrenci ve ögretmenlerin sahip oldukları okul algıları ile ideal okul algilarının metaforlar (mecazlar) yardımıyla analizi. [The analysis of perceptions that primary students and teachers have on the school life and ideal school life by using metaphors]. Unpublished master's thesis, Eskişehir Osmangazi Üniversitesi: Eskişehir, 2008.

[23] Y. Cerit. Öğretmen kavrami ile ilgili metaforlara ilişkin öğrenci, öğretmen ve yöneticilerin görüşleri. [Students, teachers and administrators' views on metaphors with respect to the concept of teacher], Türk Eğitim Bilimleri Dergisi, Vol.6, No.4, 693-712, 2008.

[24] G. Ocak, M. Gündüz. Eğitim fakültesini yeni kazanan öğretmen adaylarının öğretmenlik mesleğine giriş dersini almadan önce ve aldıktan sonra öğretmenlik mesleğ hakkındaki metaforlarının karşılaştırılması. [The comparison of pre-service teachers' metaphors about the teacher-profession before and after the 'introduction to teacher-profession' course] Afyon Kocatepe Üniversitesi Sosyal Bilimler Dergisi, Vol. 8, No. 2, 293-311, 2006.

[25] C. Öztürk. Sosyal bilgiler, sınıf ve fen bilgisi öğretmen adaylarının 'coğrafya' kavramına yönelik metafor durumları. [Metaphor status about the concept of 'geography' of prospective social science, science and classroom teachers], Ahi Evran Üniversitesi Kırşehir Eğitim Fakültesi Dergisi (KEFAD), Vol. 8, No. 2, 55-69, 2007.

[26] A. Saban. İlköğretim I. kademe öğretmen ve öğrencilerinin bilgi kavramına ilişkin sahip oldukları zihinsel imgeler. [Primary school teachers' and their students' mental images about the concept of knowledge], İlkögrretim Online, Vol. 7 , No. 2, 421-455, 2008.

[27] K. S. Moser. Metaphor analysis in psychology-Method, theory, and fields of application. In Forum Qualitative Sozialforschung/Forum: Qualitative Social Research, Vol. 1, No. 2. 2000

[28] A. Yıldırım, H. Şimşek. Sosyal bilimlerde nitel araştırma yöntemleri. Ankara: Seçkin Yayıncılık, 2011

[29] D. Ekiz. Bilimsel araştırma yöntemleri. Ankara: Anı Yayıncilık, 2009.

[30] M. B. Miles, A. M. Huberman. Qualitative data analysis. Thousand Oaks, CA: Sage, 1994. 
[31] Y. Ucun, S. Mersin, E. Öksüz. Gençlerin yaşlı bireylere karşı tutumu [The attitude of young people towards elderly people]. Uluslararası Sosyal Araştırmalar Dergisi, Vol. 8, 1143-1149, 2015.

[32] O. Hazer. Büyük ebeveynlerinin ergenler tarafından algılanan özelliklerini etkileyen faktörlerin incelenmesi. Edebiyat Fakültesi Dergisi, Vol. 29, No. 1, 70-83, 2012.

[33] O. Hazer. Ergenlerin büyük ebeveynlerinden beklentilerini etkileyen faktörlerin incelenmesi. Hacettepe Üniversitesi Sosyolojik Araştırmalar E-Dergisi, 1-22, 2011.

[34] B. Ögel. Türk mitolojisi-II [Turkish mythology], Türk Tarih Kurumu Basımevi, Ankara, 1995.

[35] R. R. McCrae, P. T. Costa. The stability of personality: Observations and evaluations. Current Directions in Psychological Science, Vol. 3, No.6, 173-175, 1994.

[36] Ö. Z. Altan. Sosyal politika [Social policy], Anadolu Üniversitesi Yayınları, Eskişehir, 2006

[37] Z. Uçanok, Gelişimsel düzenleme modeli çerçevesinde genç yetișkin, orta yaș ve yaşlilikta kontrol stratejilerinin incelenmesi. Unpublished doctoral dissertation, Hacettepe University, Ankara, 2001.

[38] F. Taşç1, Refah devleti modelleri içinde Türkiye'nin pozisyonu: "Yaşlı algısı" üzerinden değerlendirmeler [Turkey's position within the models of welfare states: Evaluations through "the perception of old-age"], Human \& Society, Vol.3, No.5, 5-35, 2013.

[39] Ö.Z. Altan, Y. Şişman. Yaşlilara yönelik sosyal politikalar [Social policies for the elderly], Kamu-Işs $\dot{I}_{S ̧} H u k u k u$ ve Iktisat Dergisi, Vol. 7, No. 2, 2-36, 2003.

[40] N. Bilgili. Yaşlı bireye bakım veren ailelerin karşılaştıkları sorunların belirlenmesi. Unpublished doctoral dissertation, Hacettepe University, Ankara, 2000.

[41] B. Çatak, Ö. Can, A.S. Kılınç, S. Sütlü, S. Şenbayram. Yașlilara evde bakım verenlerde ruhsal hastalık belirtisi sıklığ1 ve etkileyen faktörler [Frequency and affecting factors of psychiatric symptoms of caregivers of elderly people], Kafkas Journal of Medical Sciences, Vol. 2, No. 3, 105-108, 2012. 